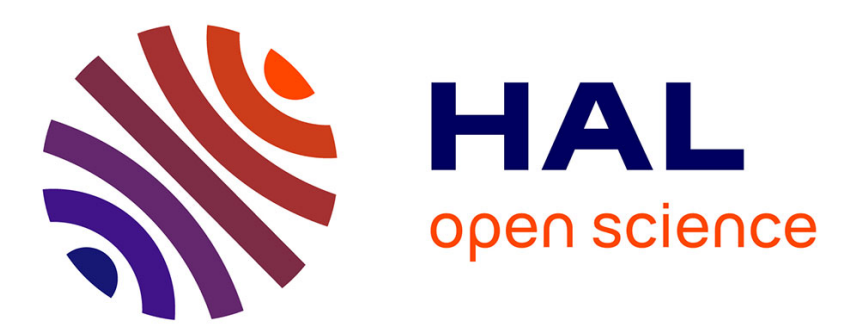

\title{
Corrosion inhibition of copper in neutral chloride media by a novel derivative of 1,2,4-triazole
}

Zoulicka Khiati, A.A. Othman, M. Sanchez-Moreno, Marie-Claude Bernard, Suzanne Joiret, Eliane Sutter, Vincent Vivier

\section{- To cite this version:}

Zoulicka Khiati, A.A. Othman, M. Sanchez-Moreno, Marie-Claude Bernard, Suzanne Joiret, et al.. Corrosion inhibition of copper in neutral chloride media by a novel derivative of 1,2,4-triazole. Corrosion Science, 2011, 53 (10), pp.3092-3099. 10.1016/j.corsci.2011.05.042 . hal-00816561

\section{HAL Id: hal-00816561 \\ https://hal.sorbonne-universite.fr/hal-00816561}

Submitted on 14 Apr 2015

HAL is a multi-disciplinary open access archive for the deposit and dissemination of scientific research documents, whether they are published or not. The documents may come from teaching and research institutions in France or abroad, or from public or private research centers.
L'archive ouverte pluridisciplinaire HAL, est destinée au dépôt et à la diffusion de documents scientifiques de niveau recherche, publiés ou non, émanant des établissements d'enseignement et de recherche français ou étrangers, des laboratoires publics ou privés. 


\title{
Corrosion inhibition of copper in neutral chloride media by a novel
}

\section{derivative of 1,2,4-triazole}

\author{
Z. Khiati, ${ }^{\mathrm{a}, \mathrm{b}, \mathrm{c}}$ A.A. Othman, ${ }^{\mathrm{c}}$ M. Sanchez-Moreno, ${ }^{\mathrm{a}, \mathrm{b}}$ M-C. Bernard, ${ }^{\mathrm{a}, \mathrm{b}}$ \\ S. Joiret, ${ }^{\mathrm{a}, \mathrm{b}}$ E.M.M. Sutter, ${ }^{\mathrm{a}, \mathrm{b},{ }^{*}}$ V. Vivier ${ }^{\mathrm{a}, \mathrm{b}}$
}

${ }^{a}$ LISE, UPR 15 du CNRS, Université Pierre et Marie Curie, CP 133, 4 Place Jussieu, 75252 Paris Cedex 05 - France

${ }^{b}$ University Pierre et Marie Curie, 4 place Jussieu, 75252 Paris Cedex 05, France

${ }^{c}$ Laboratoire de Chimie Organique Bioactive, Université des Sciences et de la Technologie d'Oran, B.P. 1505, El Mnaouer, Oran, Algeria.

*Corresponding author. Tel.: +331442741 68; fax: +33 144274074

E-mail address: eliane.sutter@upmc.fr (E.M.M. Sutter) 


\begin{abstract}
The efficiency of a new corrosion inhibitor, the bis-(4-amino-5-mercapto-1,2,4-triazol3-yl)-butane (BAMTB), on copper was investigated in an aerated $3 \% \mathrm{NaCl}$ solution using various techniques. Voltammetry, chronopotentiometry and electrochemical impedance spectroscopy (EIS) were performed to evaluate the inhibition efficiency of BAMTB. The surface layers were also characterized by Raman micro-spectroscopy and by scanning electron microscopy (SEM) coupled with energy dispersive X-ray spectroscopy (EDX). Potentiodynamic polarization curves showed that BAMTB is a mixed-type inhibitor for copper in neutral chloride solution and is even more efficient than the reference compound benzotriazole.
\end{abstract}
Keywords:
A: Copper
B: EIS
B: Raman spectroscopy
B: Polarization
$C$ : Neutral inhibition 


\section{Introduction}

The most widely used inhibitors in the field of copper corrosion in chloride containing media are azole derivatives. They have been [1-9] and still are the subject of numerous investigations, as shown by the publication of recent reviews $[10,11]$ in this domain. Among the azole-type compounds, benzotriazole (BTA) [12-19] is the most used inhibitor from a practical point of view, because it shows very high inhibition efficiency in neutral-chloride containing aqueous solutions. In the case of BTA, it seems well established that it acts through the formation of a $\mathrm{Cu}(\mathrm{I})-\mathrm{BTA}$ complex involving $\mathrm{Cu}-\mathrm{N}$ bonds [20-22], but the number of $\mathrm{N}$-atom involved in the bond, the orientation of the complex at the metal surface, and the influence of the benzenic ring on the inhibition efficiency are not completely understood. In order to increase the strength of bonding between copper(I) and the organic molecule, different azole derivatives were investigated, changing the number or position of substituent groups and the number of nitrogen atoms on the azole ring, or adding another heteroatom like sulphur [23, 24]. For instance, 1,2,4-triazole [25-29] and its amino derivatives, tetrazole $[19,26]$, thiadiazole $[10,30,31]$, pyrazole $[32,33]$, imidazole [34-36] and the corresponding derivatives have been suggested. These inhibitors have also been studied as corrosion inhibitors of copper based material such as bronzes [31, 37-39]. Nevertheless, to our best knowledge, the inhibition efficiency of BTA could not be improved up to now.

The aim of this paper is to present the remarkable inhibiting properties of a new corrosion inhibitor synthesized in our laboratory, as a derivative of 1,2,4-triazole, containing two mercapto groups and two amino groups: The efficiency of bis-(4-amino-5-mercapto1,2,4-triazol-3-yl)-butane (BAMTB) towards copper corrosion is investigated in an air saturated $3 \% \mathrm{NaCl}$ solution, using electrochemical methods such as voltammetry and impedance spectrometry. The inhibition efficiency is followed as a function of immersion 
time at open-circuit potential, in the presence of two different inhibitor concentrations (1.0 and $8.9 \mathrm{mmol} \mathrm{L}^{-1}$ ). The efficiency of the inhibitor is also tested in the anodic domain for which significant dissolution is assumed to occur in absence of inhibitor. Finally the mechanism of inhibition will be discussed from electrochemical results, SEM observations, and from EDX and Raman spectrometry analyses.

\section{Experimental}

\subsection{Reagents}

The corrosive medium was an aqueous aerated $3 \% \mathrm{NaCl}$ solution prepared from deionised water and analytical grade chemicals used as received.

For this work, the organic inhibitor BAMTB (Figs. 1a) was synthesized according to literature [40] by means of cyclization of adipic dihydrazide with $\mathrm{CS}_{2}$ and $\mathrm{KOH}$ followed by one-pot reaction with hydrazine hydrate. After synthesis, the composition and purity of the product were checked using FT-IR, UV-Visible and NMR spectrometries (spectra not shown). The corresponding structure is reported in Fig. 1a and for comparison, benzotriazole usually considered as a reference inhibitor for $\mathrm{Cu}$ is also depicted in Fig. 1b. Various concentrations ranging from $1 \mu \mathrm{mol}$ to $8.9 \mathrm{mmol} \mathrm{\textrm {L } ^ { - 1 }}$ of BAMTB in $3 \% \mathrm{NaCl}$ solutions were prepared. It should be mentioned that the latter value corresponds to the solubility limit of BAMTB in aqueous solution.

\subsection{Methods}

Electrochemical experiments were carried out in a conventional three-electrode cell. A platinum gauze was the counter electrode, a $\mathrm{Cu}$ rotating-disk electrode was the working electrode and a saturated calomel electrode (SCE) was the reference electrode. The working electrode was prepared from a cylindrical copper rod (99.999 \% purity, Goodfellow). The 
lateral part was coated with a cataphoretic paint and embedded in an epoxy resin to expose a disk with a cross-section area of $0.63 \mathrm{~cm}^{2}$. The electrode was mechanically ground with $\mathrm{SiC}$ abrasive papers (grade 600, 1200, 2800 and 4000), rinsed with deionised water, degreased with ethanol under sonication, washed with deionised water, and finally dried with an inert gas flux at room temperature.

All electrochemical measurements were carried out in a Faraday cage with a Gamry potentiostat (model PC4/300). The polarization curves were measured after a stable corrosion potential $E_{\text {corr }}$ was reached (about $1 \mathrm{~h}$ after immersion in an aerated $3 \% \mathrm{NaCl}$ solution). The cathodic and anodic polarization curves were measured at a scan rate of $1 \mathrm{mV} / \mathrm{s}$. Electrochemical impedance spectroscopy (EIS) measurements were performed in potentiostatic mode over a frequency range from $100 \mathrm{kHz}$ down to $10 \mathrm{mHz}$. The sine wave perturbation was $10 \mathrm{mV}$ in amplitude with 10 points per decade. All electrochemical measurements were performed at room temperature, with a rotating disk at $1000 \mathrm{rpm}$.

The surface morphology of the samples was investigated with a LEICA STEREOSCAN 440 scanning electron microscope (SEM). The elemental composition of the corrosion product layer and of the protective film of inhibitor formed at the surface were characterized by quantitative energy dispersive X-ray spectroscopy (EDX) coupled to the SEM observations.

The Raman micro-spectroscopy analysis was carried out with a Labram-Jobin-Yvon spectrometer. The samples were irradiated with a He-Ne laser at $\lambda=632.8 \mathrm{~nm}$. The laser power was varied between 0.1 and $1 \mathrm{~mW}$ to avoid any thermal effect on sample during the analyses. A confocal microscope was used and the investigated area was limited to $5 \mu \mathrm{m}^{2}$ using a 80 ULWD objective lens.

\section{Results and discussion}




\subsection{Polarization curves}

Both, the anodic and cathodic polarization curves were obtained starting from $E_{\text {corr }}$ after one hour immersion, during two independent experiments, but they are reported in the same figure (Fig. 2).

\section{In absence of BAMTB}

The anodic dissolution of copper in neutral chloride media has been extensively studied [41-47]. The mechanisms of anodic dissolution of copper can be represented by the following two-step mechanism:

$$
\begin{aligned}
& \mathrm{Cu}+\mathrm{Cl}^{-} \leftrightarrows \mathrm{CuCl}_{\mathrm{ads}}+\mathrm{e}^{-} \\
& \mathrm{CuCl}_{\mathrm{ads}}+\mathrm{Cl}^{-} \leftrightarrows \mathrm{CuCl}_{2}^{-}
\end{aligned}
$$

The anodic curve for copper shows two domains (Fig. 2A). The first one spreads from the corrosion potential to about $130 \mathrm{mV} / \mathrm{SCE}$. The current firstly increases and tends towards a plateau. This indicates a diffusion-limiting rate, attributed to the mass transport of chloride ions $\left(\mathrm{Cl}^{-}\right)$to the interface and the diffusion of $\mathrm{CuCl}_{2}^{-}$in the solution following the mechanism indicated in Eqs. (1-2) [1, 48]. The second domain, for potential more positive than 130 $\mathrm{mV} / \mathrm{SCE}$, corresponds to the formation of $\mathrm{Cu}(\mathrm{II})$ species.

The cathodic reaction for copper in an aerated neutral chloride solution is the oxygen reduction reaction according to

$\mathrm{O}_{2}+2 \mathrm{H}_{2} \mathrm{O}+4 \mathrm{e}^{-} \rightarrow 4 \mathrm{OH}^{-}$

The cathodic plateau observed between -650 and $-1200 \mathrm{mV} / \mathrm{SCE}$ (Fig. 2A) is ascribed to $\mathrm{O}_{2}$ reduction and the limiting current value $\left(1 \mathrm{~mA} / \mathrm{cm}^{2}\right.$ at $\left.1000 \mathrm{rpm}\right)$ is in good agreement with literature data [49]. 
In Fig. 2, the polarization curves in the presence of BTAM are also reported for concentrations varying from $1 \mu \mathrm{mol} \mathrm{L} \mathrm{L}^{-1}$ to $8.9 \mathrm{mmol} \mathrm{L}^{-1}$, which is the limit of solubility of the inhibitor in aqueous solution.

The addition of BAMTB into the sodium chloride solution shifts the corrosion potential from $-240 \mathrm{mV} / \mathrm{SCE}$ towards a more anodic value, between -180 and $-170 \mathrm{mV} / \mathrm{SCE}$ for concentrations of $0.01 \mathrm{mmol} \mathrm{L}^{-1}$ and larger. In the potential range under study $(-1200$ to 400 $\mathrm{mV} / \mathrm{SCE}$ ), both the anodic and the cathodic currents are significantly decreased in the presence of BAMTB for concentrations above $0.01 \mathrm{mmol} \mathrm{L}^{-1}$.

In the anodic range, the limiting current density in the first domain is decreased by 5 to 6 orders of magnitude (compare for instance the value at $0 \mathrm{~V} / \mathrm{SCE}$, which is $0.02 \mathrm{~A} / \mathrm{cm}^{2}$ in the blank solution and $0.1 \mu \mathrm{A} / \mathrm{cm}^{2}$ in the presence of $8.9 \mathrm{mmol} \mathrm{L}^{-1} \mathrm{BAMTB}$ ), indicating that the formation of $\mathrm{Cu}(\mathrm{I})$ species is strongly inhibited. For more anodic potential, the current density is also much smaller than in absence of BAMTB (about 3 orders of magnitude), as a consequence of a lower rate of $\mathrm{Cu}(\mathrm{II})$ formation.

In the cathodic potential range, the plateau due to oxygen reduction is only observed in a limited potential range, for potentials lower than $-1 \mathrm{~V} / \mathrm{SCE}$. In the potential range more positive than $-1 \mathrm{~V} / \mathrm{SCE}$, the cathodic current density is lowered by about 4 orders of magnitude for $8.9 \mathrm{mmol} \mathrm{L}^{-1}$, showing that BAMTB also inhibits the oxygen reduction reaction. The simultaneous decrease of both anodic and cathodic current densities in presence of BAMTB shows that it behaves like a mixed inhibitor.

\subsection{Electrochemical impedance measurements}

3.3.1. Influence of BAMTB on the impedance diagrams 
In the following, the results are only reported for the two higher inhibitor concentrations (1.0 and $8.9 \mathrm{mmol} \mathrm{L}^{-1}$ ), which show the best inhibition efficiencies, and compared to the behaviour of copper in the $3 \% \mathrm{NaCl}$ solution.

Nyquist and Bode plots for copper in the $3 \% \mathrm{NaCl}$ solution with and without inhibitor at two different concentrations are presented in Figs. 3 and 4, respectively, after one hour of immersion.

In absence of inhibitor, two time constants can be evidenced. In the high frequency domain, the charge transfer resistance is in parallel with a capacitor. In the low frequency range, the time constant is ascribed to the diffusion of electroactive species in the corrosion product layer. When the inhibitor is added to the solution, the amplitude of the impedance spectra is much larger. The inhibition efficiency of BAMTB can be determined from the low frequency limit of the impedance (i.e. with the polarisation resistance, $R_{\mathrm{p}}$, which corresponds to the inverse of the slope of the current density - potential curve in the vicinity of $\left.E_{\text {corr }}\right)$. The polarization resistance is about $2 \mathrm{k} \Omega \mathrm{cm}^{2}$ in absence of inhibitor, whereas it reaches 1.5 and 3 $\mathrm{M} \Omega \mathrm{cm}^{2}$ in presence of 1.0 and $8.9 \mathrm{mmol} \mathrm{L}^{-1}$ of inhibitor, respectively. The direct comparison with published results obtained with BTA $\left(R_{\mathrm{p}}=40 \mathrm{k} \Omega \mathrm{cm}^{2}\right.$ for $10 \mathrm{mmol} \mathrm{L}^{-1}$ BTA [50]) indicates that BAMTB behaves as a remarkably efficient inhibitor, since in comparison with BTA, it still enhances the $R_{\mathrm{p}}$ value by nearly 2 orders of magnitude, and consequently decreases the corrosion rate by the same ratio.

In the presence of inhibitor, the loops in Nyquist representation (Fig.3) are not well resolved, showing some drift in the low frequency range, which is often observed when the systems is not stable. The capacitance $\mathrm{C}$ calculated from the characteristic frequency $f_{\max }$ of the capacitive loop indicates about $1.2 \mu \mathrm{F} \mathrm{cm} \mathrm{cm}^{-2}$ at the early stage of immersion $\left(f_{\max }=1 / 2 \pi R C\right.$ where $R$ is the diameter of the loop). This value is too low to be ascribed to the double layer 
capacitance, $C_{\mathrm{dl}}$ (that is usually between 10 and $60 \mu \mathrm{F} \mathrm{cm}$ ), and is therfore ascribed to a protective film formed in presence of inhibitor.

\subsubsection{Effect of immersion time}

The Nyquist plots of copper in $3 \% \mathrm{NaCl}$ containing $8.9 \mathrm{mmol} \mathrm{L}^{-1}$ BAMTB for various immersion times are shown in Fig. 5. As for short immersion times (Figs. 3 and 4), all Nyquist diagrams are characterised by a single loop. The polarization resistance, determined by extrapolation at the low frequency limit of the impedance spectra, significantly increases with increasing immersion time, from $5.5 \mathrm{M} \Omega \mathrm{cm}^{2}$ after $2 \mathrm{~h}$ immersion to $21.5 \mathrm{M} \Omega \mathrm{cm}^{2}$ after 30h immersion (Fig. 6), showing that the inhibition efficiency further increases.

The film capacitance further decreases when immersion time increases, from $1.2 \mu \mathrm{F}$ $\mathrm{cm}^{-2}$ at the early stage of immersion, towards $0.5 \mu \mathrm{F} \mathrm{cm}$ after 30 hours (Fig. 6). This evolution indicates a thickening with time of the protective layer, and is in agreement with the drift of the measurements observed in the low frequency range at short immersion times (Fig. 3).

According to the model of the parallel-plate capacitor [51], the thickness $(d)$ of the protective film can be calculated from the capacitance of the film $\left(C_{\mathrm{f}}\right)$ by the following expression

$$
d=\frac{\varepsilon \varepsilon_{0}}{C_{\mathrm{f}}}
$$

where $\varepsilon_{0}$ is the vacuum permittivity $\left(8.8510^{-14} \mathrm{~F} \mathrm{~cm}^{-1}\right)$, and $\varepsilon$ is the dielectric constant of the film (a mean value of 4 is usually used for this kind of material [52]).

Fig. 7 shows the variation of the calculated film thickness with the immersion time of copper in an inhibitor containing chloride solution. The thickness gradually increases with time corresponding to a continuous evolution of the interface. Nonetheless, the film remains thin, only $7 \mathrm{~nm}$ after 30 hours immersion, but the corresponding increase of the polarisation resistance (Fig. 6) indicates that the film is compact and very protective. 


\subsection{Ex-situ characterization of the inhibitor film formed at open circuit potential}

In order to confirm the effect of BAMTB for longer immersion periods, the copper electrode was immersed in the chloride solution at $1000 \mathrm{rpm}$ without and with inhibitor during one week at the open circuit potential. The samples were then characterized using SEM coupled with EDX analysis, and Raman micro-spectrometry.

\subsubsection{Scanning electron microscopy (SEM) / energy dispersive X-ray analysis (EDX)}

SEM images of copper surfaces are shown in Fig. 8. Before immersion, some strips due to the $\mathrm{SiC}$ grains of the abrasive paper used during the grinding procedure can be seen (Fig. 8a). After one week of immersion in $3 \% \mathrm{NaCl}$ (Fig. 8b) the sample was severely corroded and no protective layer was formed. EDX investigation evidenced $\mathrm{Cu}, \mathrm{Cl}$, and $\mathrm{O}$ at the copper electrode surface (Fig. 9a) as expected. This is in agreement with the usual composition of corrosion products formed on copper after a few days in a sodium chloride solution, namely $\mathrm{CuCl},\left(\mathrm{Cu}_{2}(\mathrm{OH})_{3} \mathrm{Cl}\right)$ (atacamite) and $\mathrm{Cu}_{2} \mathrm{O}$ [53]. The mechanism of formation has been reported to be first the hydrolysis of a $\mathrm{CuCl}$ deposit into a porous layer of $\mathrm{Cu}_{2} \mathrm{O}$ (Eq. 8), which further hydrolyses to form a top layer of atacamite (Eq. 9)

$$
\begin{aligned}
& 2 \mathrm{CuCl}+\mathrm{H}_{2} \mathrm{O} \rightarrow \mathrm{Cu}_{2} \mathrm{O}+2 \mathrm{H}^{+}+2 \mathrm{Cl}^{-} \\
& \mathrm{Cu}_{2} \mathrm{O}+\mathrm{Cl}^{-}+2 \mathrm{H}_{2} \mathrm{O} \rightarrow \mathrm{Cu}_{2}(\mathrm{OH})_{3} \mathrm{Cl}+\mathrm{H}^{+}+2 \mathrm{e}^{-}
\end{aligned}
$$

Conversely, when the same experiment was performed in $8.9 \mathrm{mmol} \mathrm{L}^{-1}$ BAMTB containing solution (Fig. 8c), the surface did not seem to be attacked, and the electrode surface was bright. In addition, the small strips visible in Fig. 8a were no longer visible, which can suggest a slow dissolution giving rise to an electropolished interface. One can guess that the small amount of copper that dissolves in the early stage of corrosion is involved 
in the thin protective film formation process. Moreover, only copper and sulphur were detected by EDX analysis (Fig. 9b). This is attributed to the ability of BAMTB molecules to form a protective layer on the copper surface and hence preventing copper pitting and general corrosion. It is known that the effectiveness of an organic compound as corrosion inhibitor depends on its structure, and mainly on the number and position of heteroatoms present in the molecule [54]. Since BAMTB contains two sulphur atoms and eight nitrogen atoms as reactive centres, it can chemically adsorb on the metal surface through the interaction of lone pairs of electrons of $\mathrm{S}$ and $\mathrm{N}$ atoms. It can also interact via the $\pi$ electrons of the triazole ring $[55,56]$ which still enhances the inhibition efficiency

\subsubsection{Raman spectroscopy}

In a $3 \% \mathrm{NaCl}$ solution without inhibitor, the spectrum (a) of Fig. 10 was obtained on the copper electrode after one week of immersion. The main bands are located at $511 \mathrm{~cm}^{-1}$ with two triplets at $900-1000 \mathrm{~cm}^{-1}$ and $3300-3400 \mathrm{~cm}^{-1}$, They are characteristic of copper hydroxychloride (atacamite) $\mathrm{Cu}_{2}(\mathrm{OH})_{3} \mathrm{Cl}$ as expected $[57,58]$.

The spectrum of the inhibitor in the solid state is given in Fig. 10 spectrum (b) and the attribution of the main bands are given in Table 1 on the basis of literature data [59] from $a b$ initio calculations and experimental values of the parent compound bis (4-amino-5-mercapto1,2,4 triazol-3-yl) ethane. The latter differs from the compound presently studied, only by the lack of two methyl groups in the alkyl chain, without symmetry modifications. The lack of S$\mathrm{H}$ stretching band in this spectrum (expected near $2500-2600 \mathrm{~cm}^{-1}$ ) indicates that in the solid state BAMTB exists in the thione form (Fig. 1a). There is an ambiguity in literature on the position of the stretching vibration $\mathrm{C}=\mathrm{S}$, given at $1100-1200 \mathrm{~cm}^{-1}$ or $500-550 \mathrm{~cm}^{-1}$ depending on the authors $[59,60]$. However when the stretching band is given in the higher position, the band at $500-550 \mathrm{~cm}^{-1}$ is given as the bending mode of $\mathrm{C}=\mathrm{S}$. 
The spectrum recorded on the copper electrode after one week of immersion in $3 \%$ $\mathrm{NaCl}+8.9 \mathrm{mmol} \mathrm{L}^{-1}$ BAMTB is shown in Fig. 10 (c). The first feature of this spectrum is a doublet at 450 and $630 \mathrm{~cm}^{-1}$ characteristic of the passive layer on copper mainly composed of $\mathrm{Cu}(\mathrm{I})$ oxide (cuprite) and the main band of this crystalline compound appears also in the spectrum at $220 \mathrm{~cm}^{-1}$ [61]. In comparison with spectrum (a) of Fig. 10, a first difference when inhibitor is present in the solution is the absence of $\mathrm{Cu}(\mathrm{II})$ salts at the electrode surface.

Bands corresponding to the inhibitor are also observed at the copper surface and are reported in Table 1. Some are unchanged, in particular the one corresponding to the amino substitute and also the part of the cycle close to the alkyl chain. The bands belonging to N-H and $\mathrm{C}(\mathrm{S})-\mathrm{N}$ vibrations do not appear anymore and two new vibrations in the $\mathrm{C}=\mathrm{N}$ range at $1550 \mathrm{~cm}^{-1}$ and $\mathrm{C}-\mathrm{S}$ at $730 \mathrm{~cm}^{-1}$ are visible in the spectrum recorded on the metal surface. This type of modifications have already been encountered when a parent molecule (the phenyltriazolethione) has been used as corrosion inhibitor for bronze [37] and attributed to the formation of a bond between $\mathrm{Cu}(\mathrm{I})$ and the molecule in the thiol form (Fig. 1a), after deprotonation of the thiol. The same conclusions are valid in this study. Moreover in the case of BAMTB, the enhancement of the vibrations corresponding to the group $(\mathrm{C}=\mathrm{N}-\mathrm{N}=\mathrm{C})$ of the triazole in thiolate form can be attributed to a resonance in this particular configuration where a strong delocalisation of $\pi$ electrons is allowed. Due to the overlapping of the bands of $\mathrm{C}=\mathrm{S}$ and copper oxide, it is not possible to conclude whether or not the interaction of the molecule with copper ions involves one or two of the available thiol functions. It should also be mentioned that below $500 \mathrm{~cm}^{-1}$, attribution of Raman bands of hetero cyclic compounds is a really difficult task due to the overlapping between different possibilities (deformation or torsion of the cycles or the alkyl chains). 
In conclusion, Raman spectrometry evidenced at least one bond between copper(I) and BAMTB in the thiol form, leading to a thiol-complex, but it is yet not clear if one or two sulphur atoms of the inhibitor are involved in the bonding.

\subsection{Inhibition efficiency of BAMTB in the anodic potential range}

\subsubsection{Chronoamperometric measurements}

The previous ex-situ analyses indicated that some copper species generated during the corrosion process should be involved in the formation of the protective film. Some experiments were performed at anodic potential in order to control the generation of $\mathrm{Cu}(\mathrm{I})$ or $\mathrm{Cu}(\mathrm{II})$ species. According to the anodic curves presented in Fig. 2, a potential value of 150 $\mathrm{mV} / \mathrm{SCE}$ was applied in order to increase the dissolution rate of copper. The chronoamperometric curves shown in Fig. 11 were obtained in $3 \% \mathrm{NaCl}$ solution for a copper electrode biased at $150 \mathrm{mV} / \mathrm{SCE}$ without (Fig. 11a) and with $8.9 \mathrm{mmol} \mathrm{L}^{-1}$ of BAMTB (Fig. 11b). In absence of inhibitor, the current density remains close to $25 \mathrm{~mA} \mathrm{~cm}^{-2}$ during all the duration of the experiment. Conversely, in presence of BAMTB, the current density stabilized at $16 \mathrm{nA} \mathrm{cm}$ after $3 \mathrm{~h}$. This was ascribed to the presence of a protective film at the surface which blocks the corrosion sites at the copper surface.

\subsubsection{SEM / EDX analysis after polarization in the anodic range}

After $180 \mathrm{~min}$ of polarization at $150 \mathrm{mV} / \mathrm{SCE}$, the morphology and nature of corrosion products covering the electrode were analysed by SEM and EDX in absence and in presence of BAMTB (Fig. 12).

The surface exposed to the $3 \% \mathrm{NaCl}$ solution showed a porous structure. The surface was attacked and completely covered with corrosion products. EDX analysis used to obtain qualitative information about the compounds formed on the copper surface, evidenced the 
presence of oxygen and chlorine. This is in agreement with the expected compounds which are usually observed after polarization in this potential range: cuprous chloride $(\mathrm{CuCl})$ and cuprite $\mathrm{Cu}_{2} \mathrm{O}$.

In the presence of BAMTB, the surface of the copper electrode remains smooth and bright (similarly to what we observed at the corrosion potential), and neither $\mathrm{O}$ nor $\mathrm{Cl}$ were detected through EDX analysis. This is also in good agreement with the very low corrosion current density measured during the anodic potentiostatic treatment (Fig. 11b), and with a high rate of coverage of the copper surface by BAMTB molecules. The presence of inhibitor at the surface after polarisation at $150 \mathrm{mV} / \mathrm{SCE}$ was also confirmed by EDX analysis which showed the presence of sulphur atom.

\section{Conclusions}

These experimental results clearly showed that BAMTB is an excellent corrosion inhibitor in neutral aqueous sodium chloride solutions, with a higher efficiency than the widely used benzotriazole. Potentiodynamic measurements indicated that BAMTB acts as a mixed inhibitor, lowering simultaneously the anodic process (dissolution of copper) and the cathodic process (oxygen reduction) and changing the overall mechanism. In addition, it was shown that the inhibition efficiency of BAMTB increased with time of immersion and with inhibitor concentration up to $8.9 \mathrm{mmol}$, which is the maximum solubility of the inhibitor in aqueous solution.

Potentiostatic current-time measurements at $150 \mathrm{mV} / \mathrm{SCE}$ indicated that the presence of BAMTB lowers significantly the current values in the anodic range, and scanning electron micrographs showed that BAMTB inhibits the corrosion of copper in $3 \% \mathrm{NaCl}$ medium, by forming a thin but very protective film (few nanometres) at the active sites of the metallic surface, hindering the formation of cuprous chloride, cuprite, and atacamite. The film 
formation was characterized by Raman spectroscopy and EDX analyses, which showed that BAMTB coordinates with copper at the surface of the electrode via its sulphur atom, leading to a thiol-complex.

\section{Acknowledgements}

The authors gratefully acknowledge F. Pillier (UPR 15 - CNRS) for SEM and EDX observations. 


\section{References}

[1] G. Kear, B.D. Barker, F.C. Walsh, Corros. Sci. 46 (2004) 109-135.

[2] F. Ammeloot, C. Fiaud, E. M. M. Sutter, Electrochim. Acta 44 (1999) 2549-2558.

[3] E. M. M. Sutter, B. Millet, C. Fiaud, D. Lincot, J. Electroanal. Chem. 386 (1995) 101-109.

[4] H. O. Curkovic, E. Stupnisek-Lisac, H. Takenouti, Corros. Sci. 51 (2009) 2342-2348.

[5] A. Jardy, A. L. Lasalle-Molin, M. Keddam, H. Takenouti, Electrochim. Acta 37 (1992) 2195-2201.

[6] Z. Y. Chen, D. Persson, F. Samie, S. Zakipour, C. Leygraf, J. Electrochem. Soc. 152 (2005) B502-511.

[7] D. Persson, C. Leygraf, J. Electrochem. Soc. 142 (1995) 1468-1477.

[8] O. Blajiev, A. Hubin, Electrochim. Acta 49 (2004) 2761-2770.

[9] Y. Van Ingelgem, A. Hubin, J. Vereecken, Electrochim. Acta 52 (2007) 7642-7650.

[10] M. M. Antonijevic, S. M. Milic, M. B. Petrovic, Corros. Sci. 51 (2009) 1228-1237.

[11] M. Finsgar, I. Milosev, Corros. Sci. 52 (2010) 2737-2749.

[12] I.Dugdale, J.B.Cotton, Corros. Sci. 3 (1963) 69-74.

[13] J.P. Cotton, I.R. Scholes, Br. Corros. J. 2 (1967) 1-5.

[14] F. Mansfeld, T. Smith, E. P. Parry, Corrosion 27 (1971) 289-294.

[15] F. Mansfeld, T. Smith, Corrosion 29 (1973) 105-107.

[16] R. Walker, Corrosion 29 (1973) 290-296.

[17] D. Tromans, J. C. Silva, J. Electrochem. Soc. 143 (1996) 458-465.

[18] W. Qafsaoui, C. Blanc, N. Pebere, H. Takenouti, A. Srhiri, G. Mankowski, Electrochim. Acta 47 (2002) 4339-4346.

[19] B. Trachli, M. Keddam, H. Takenouti, A. Srhiri, Corros. Sci. 44 (2002) 997-1008.

[20] D. Chadwick, T. Hashemi, Corros. Sci. 18 (1978) 39-51.

[21] D. Chadwick, T. Hashemi, Surf. Sci. 89 (1979) 649-659. 
[22] G. Schmitt, Br. Corros. J. 19 (1984) 165-176.

[23] F. Ammeloot, C. Fiaud, E.M.M. Sutter, Electrochim. Acta 42 (1997) 3565-3574.

[24] E.M.M. Sutter, F. Ammeloot, M.J. Pouet, C. Fiaud, R. Couffignal, Corros. Sci. 41 (1999) $105-115$.

[25] D. Thierry, C. Leygraf, J. Electrochem. Soc. 133 (1986) 2236-2239.

[26] P. G. Fox, P. A. Bradley, Corros. Sci. 20 (1980) 643-649.

[27] E.S.M. Sherif, R.M. Erasmus, J.D. Comins, J. colloid Interf. Sci. 309 (2007) 470-477.

[28] E.S.M. Sherif, R.M. Erasmus, J.D. Comins, J. colloid Interf. Sci. 311 (2007) 144-151.

[29] S.El Issami, L. Bazzi, M. Mihit, B.Hammouti, S. Kertit, E. Ait Addi, R. Salghi, Pigment Resin technol. 36 (2007) 161-168.

[30] E. S. M. Sherif, J. Mater. Eng. Perf. 19 (2010) 873-879.

[31] S. Varvara, L. M. Muresan, K. Rahmouni, H. Takenouti, Corros. Sci. 50 (2008) 25962604.

[32] I. R. Fernando, N. Daskalakis, K. D. Demadis, G. Mezei, New J. Chem. 34 (2010) 221 235.

[33] E. Geler, D. S. Azambuja, Corros. Sci. 42 (2000) 631-643.

[34] H. Otmacic, E. Stupnisek-Lisac, Electrochim. Acta 48 (2003) 985-991.

[35] M. Scendo, M. Hepel, J. Electroanal. Chem. 613 (2008) 35-50.

[36] Y. Q. Tian, H. J. Xu, L. H. Weng, Z. X. Chen, D. Y. Zhao, X. Z. You, Euro. J. Inorg. Chem. 2004 (2004) 1813-1816.

[37] A. Dermaj, N. Hajjaji, S. Joiret, K. Rahmouni, A. Srhiri, H. Takenouti, V. Vivier, Electrochim. Acta 52 (2007) 4654-4662.

[38] G. Herting, S. Goidanich, I. O. Wallinder, C. Leygraf, Environ. Monit. Assess. 144 (2008) 455-461. 
[39] M. Serghini-Idrissi, M. C. Bernard, F. Z. Harrif, S. Joiret, K. Rahmouni, A. Srhiri, H. Takenouti, V. Vivier, M. Ziani, Electrochim. Acta 50 (2005) 4699-4709.

[40] Z. Khiati, A. A. Othman, S. Afr. J. Chem. 60 (2007) 20-24.

[41] E. D’Elia, O. E.Barcia, O. R.Mattos, N. Pébère, B. Tribollet, J. Electrochem. Soc. 143 (1996) 961-967.

[42] O.E. Barcia, O.R. Mattos, N. Pébère, B. Tribollet, J. Electrochem. Soc. 140 (1993) 28252832.

[43] C. Deslouis, O.R. Mattos, B. Tribollet, Electrochim. Acta 38 (1993) 2781-2783.

[44] H.P. Lee, K. Nobe, J. Electrochem. Soc. 133 (1986) 2035-2043

[45] D. Tromans, R. Sun, J. Electrochem. Soc. 138 (1991) 3235-2344.

[46] A. Moreau, J.P. Frayret, F. Del Rey, R. Pointeau, Electrochim. Acta 27 (1982) 12811291.

[47] W.D. Bjorndahl, K. Nobe, Corrosion 40 (1984).82-87.

[48] L. Bacarella, J.C. Griess, J. Electrochem. Soc. 120 (1973) 459-465.

[49] C. Deslouis, B. Tribollet, G. Mengoli, M.M. Musiani, J. Appl. Electrochem. 18 (1988) 384-393.

[50] F. E.-T. Heakal, S. Haruyama, Corros. Sci. 20 (1980), 887-898.

[51] A. J. Bard, L.R. Faulkner, in Electrochemical Methods: Fundamentals and Applications Second Edition; John Wiley and Sons: New York, 2001.

[52] H.-L. Wang, H.-B. Fan, J.-S. Zheng, Mat. Chem. Phys. 77 (2002).655-661.

[53] A. Kratschmer, I. Odnevall Wallinder, C. Leygraf, Corros. Sci. 44 (2002) 425-450.

[54] B. Donnelly, T. C. Downie, R. Grzeskowiak, H. R. Hamburg, D. Short, Corros. Sci. 18 (1978) 109-116.

[55] G. Banerjee, S. N. Malhotra, Corrosion 48 (1992) 10-15.

[56] R. Agarwal, T. K. G. Namboodhiri, J. Appl. Electrochem. 22 (1992) 383-389. 
[57] R.L. Frost, Spectrochim. Acta A 59 (2003) 1195-1204.

[58] V. Hayez, V. Costa, J. Guillaume, H. Terryn, A. Hubin, Analyst, 130 (2005) 550-556.

[59] S. Subashchandrabose, A. R. Krishnan, H. Saleem, V. Thanikachalam, G.Manikandan, Y. Erdogdu, J. Molecular Struct. 981 (2010) 59-70.

[60] A. Elhajji, N. Ouijja, M.S. Idrissi,C. Garrigou-Lagrange, Spectrochim. Acta, Part A: 53A (1997) 699-706 and references therein.

[61] M.C. Bernard, S. Joiret, Electrochim. Acta 54 (2009) 5199-5205. 


\section{Figure captions}

Figure 1: Structure of BAMTB (a) and BTA (b).

Figure 2: Polarization curves for a copper electrode in a $3 \% \mathrm{NaCl}$ solution at $\Omega=1000 \mathrm{rpm}$ and $\mathrm{v}=1 \mathrm{mV} / \mathrm{s}$ for different BAMTB concentrations. (A) Without inhibitor; with (B) $1 \mu \mathrm{mol} \mathrm{L}{ }^{-1}$, (C) $10 \mu \mathrm{mol} \mathrm{L}{ }^{-1}$, (D) $100 \mu \mathrm{mol} \mathrm{L}^{-1}$, (E) $1 \mathrm{mmol} \mathrm{L}^{-1}$, (F) $8.9 \mathrm{mmol} \mathrm{L}^{-1}$ BAMTB.

Figure 3. Nyquist plots for the $\mathrm{Cu}$ electrode after $1 \mathrm{~h}$ immersion in a $3 \% \mathrm{NaCl}$ solution in absence $(\diamond)$, in presence of $1.0 \mathrm{mmol} \mathrm{L}^{-1}(\square)$ and $8.9 \mathrm{mmol} \mathrm{L}^{-1}(\circ)$ BAMTB. $\Omega=1000 \mathrm{rpm}$.

Figure 4: Bode plots for the $\mathrm{Cu}$ electrode after $1 \mathrm{~h}$ immersion in a $3 \% \mathrm{NaCl}$ solution in absence $(\diamond)$, in presence of $1.0 \mathrm{mmol} \mathrm{L}^{-1}(\square)$ and $8.9 \mathrm{mmol} \mathrm{L}^{-1}(\circ)$ BAMTB. $\Omega=1000 \mathrm{rpm}$.

Figure 5: Nyquist plots for the $\mathrm{Cu}$ electrode in aerated $3 \% \mathrm{NaCl}$ solution in the presence of $8.9 \mathrm{mmol} \mathrm{L}^{-1}$ BAMTB with the immersion time as a parameter. $\Omega=1000 \mathrm{rpm}$.

Figure 6: Variation of the film capacitance and the polarization resistance in a $3 \% \mathrm{NaCl}$ in presence of $8.9 \mathrm{mmol} \mathrm{L}^{-1}$ BAMTB with the immersion time as a parameter. $\Omega=1000 \mathrm{rpm}$.

Figure 7: Variation of thickness as a function of the immersion time for copper electrode in a $3 \% \mathrm{NaCl}$ in presence of $8.9 \mathrm{mmol} \mathrm{L}^{-1}$ of BAMTB. $\Omega=1000 \mathrm{rpm}$.

Figure 8: SEM images of the copper surface obtained (a) before and after 1 week immersion in a $3 \% \mathrm{NaCl}$ solution (b) without and (c) with $8.9 \mathrm{mmol} \mathrm{L}^{-1}$ BAMTB. $\Omega=1000 \mathrm{rpm}$.

Figure 9: EDX analysis of copper obtained after 1 week of immersion in a $3 \% \mathrm{NaCl}$ (a) without BAMTB and (b) with $8.9 \mathrm{mmol} \mathrm{L}^{-1}$ BAMTB. $\Omega=1000 \mathrm{rpm}$.

Figure 10: Raman spectra of: (a) copper surface after 1 week of immersion in aerated $3 \%$ $\mathrm{NaCl}$; ( b) solid BAMTB; and (c) copper surface after 1 week of immersion in aerated $3 \%$ $\mathrm{NaCl}$ with $8.9 \mathrm{mmol} \mathrm{L}^{-1}$ BAMTB

Figure 11: Chronoamperometric curves for a copper electrode biased at $150 \mathrm{mV} / \mathrm{SCE}$ in a $3 \%$ $\mathrm{NaCl}$ solution (a) in absence and (b) in presence of $8.9 \mathrm{mmol} \mathrm{L}^{-1}$ BAMTB. $\Omega=1000 \mathrm{rpm}$.

Figure 12: SEM images of the copper surface obtained after chronoamperometric experiments presented in Fig. 11. (a) without and (b) with $8.9 \mathrm{mmol} \mathrm{L}^{-1}$ BAMTB. 
Table 1: Vibrational wavenumbers and assignments for solid BAMTB and electrode surface

\begin{tabular}{|c|c|c|c|}
\hline \multicolumn{2}{|c|}{ BAMTB solid } & \multicolumn{2}{|c|}{ Electrode surface } \\
\hline $\begin{array}{c}\text { Raman } \\
\text { wavenumber } / \mathrm{cm}^{-1}\end{array}$ & Assignment & $\begin{array}{c}\text { Raman } \\
\text { wavenumber } / \mathrm{cm}^{-1}\end{array}$ & Assignment \\
\hline $\begin{array}{l}2873, \quad 2908, \quad 2944, \\
2980\end{array}$ & C-H stretching & & \\
\hline 1620 & $\mathrm{NH}_{2}$ scissoring & 1640 & $\mathrm{NH}_{2}$ scissoring \\
\hline & & 1550 & $\mathrm{~N}=\mathrm{C}(-\mathrm{S})$ stretching \\
\hline 1445,1465 & $\mathrm{~N}-\mathrm{C}(-\mathrm{S})$ stretching & & \\
\hline 1355 & N-N stretching & 1350 & N-N stretching \\
\hline 1271 & $\mathrm{~N}-\mathrm{N}$ bending & 1285 & $\mathrm{~N}-\mathrm{N}$ bending \\
\hline 1163 & $\mathrm{~N}-\mathrm{C}(=\mathrm{N})$ stretching & 1163 & $\mathrm{~N}-\mathrm{C}(=\mathrm{N})$ stretching \\
\hline 1073 & $\mathrm{~N}-\mathrm{H}$ bending & & \\
\hline 964 & $\mathrm{CH}_{2}$ torsion & 965 & $\mathrm{CH}_{2}$ torsion \\
\hline 814 & $\mathrm{CH}_{2}-\mathrm{CH}_{2}$ bending & 837 & $\mathrm{CH}_{2}-\mathrm{CH}_{2}$ bending \\
\hline & & 730 & $\mathrm{C}-\mathrm{S}(-\mathrm{Cu})$ stretching \\
\hline 507 & $\begin{array}{l}\mathrm{C}=\mathrm{S} \text { stretching or } \\
\text { bending }\end{array}$ & & \\
\hline
\end{tabular}


Figure 1: Structure of BAMTB (a) and BTA (b)

(a)<smiles>Nn1c(S)nnc1CCc1nnc(NSC=S)n1N</smiles>

(b)<smiles>c1ccc2[nH]nnc2c1</smiles> 
Figure 2: Polarization curves for a copper electrode in a $3 \% \mathrm{NaCl}$ solution at $\Omega=1000 \mathrm{rpm}$ and $\mathrm{v}=1 \mathrm{mV} / \mathrm{s}$ for different BAMTB concentrations. (A) Without inhibitor; with (B) $1 \mu \mathrm{mol} \mathrm{L}{ }^{-1}$, (C) $10 \mu \mathrm{mol} \mathrm{L}{ }^{-1}$, (D) $100 \mu \mathrm{mol} \mathrm{L}^{-1}$, (E) $1 \mathrm{mmol} \mathrm{L}^{-1}$, (F) $8.9 \mathrm{mmol} \mathrm{L}{ }^{-1}$ BAMTB.

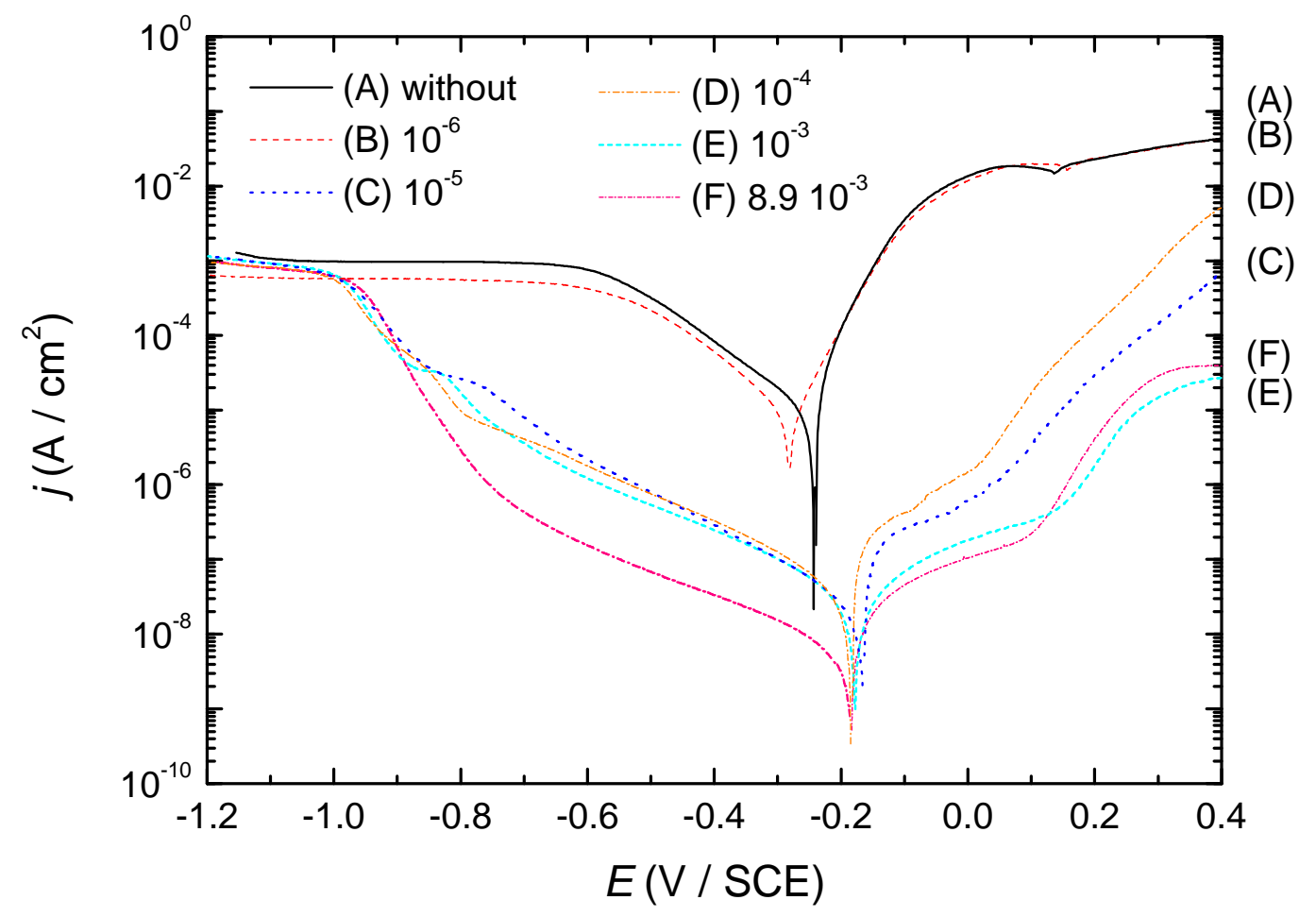


Figure 3. Nyquist plots for the $\mathrm{Cu}$ electrode after $1 \mathrm{~h}$ immersion in a $3 \% \mathrm{NaCl}$ solution in absence $(\diamond)$, in presence of $1.0 \mathrm{mmol} \mathrm{L}^{-1}(\square)$ and $8.9 \mathrm{mmol} \mathrm{L}^{-1}(\circ)$ BAMTB. $\Omega=1000 \mathrm{rpm}$.

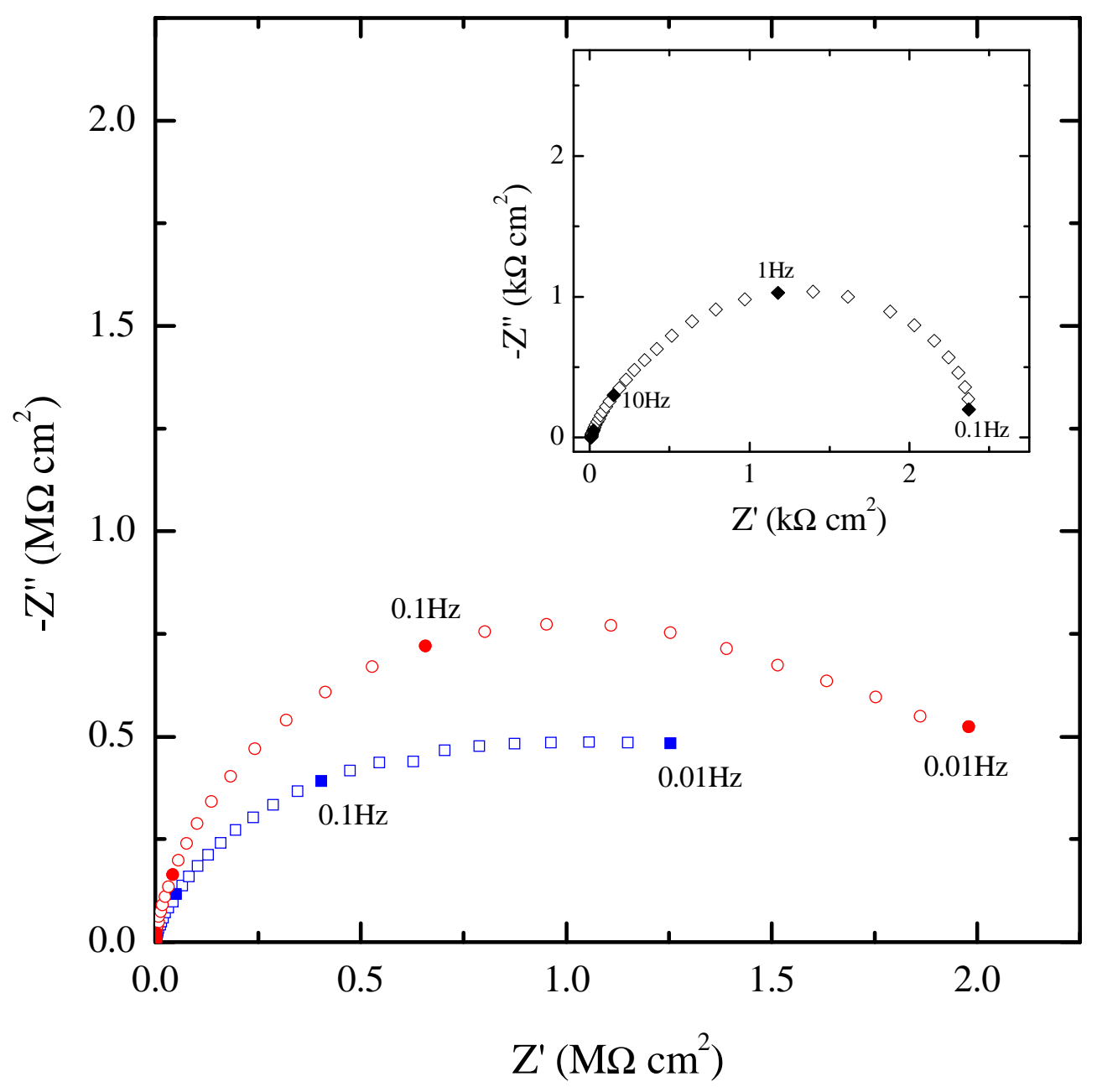


Figure 4: Bode plots for the $\mathrm{Cu}$ electrode after $1 \mathrm{~h}$ immersion in a $3 \% \mathrm{NaCl}$ solution in absence $(\diamond)$, in presence of $1.0 \mathrm{mmol} \mathrm{L}^{-1}(\square)$ and $8.9 \mathrm{mmol} \mathrm{L}^{-1}(\circ)$ BAMTB. $\Omega=1000 \mathrm{rpm}$.
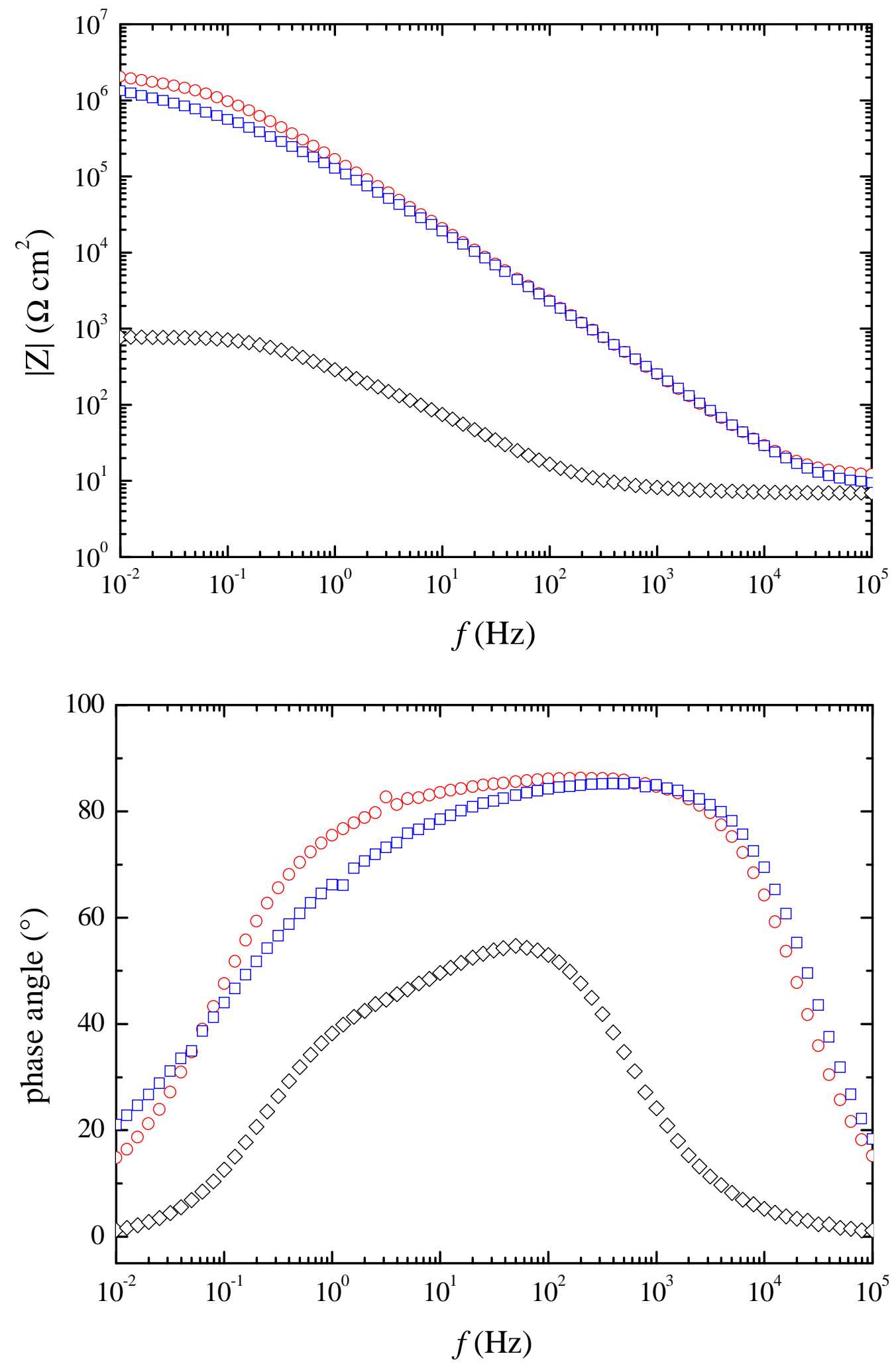
Figure 5: Nyquist plots for the $\mathrm{Cu}$ electrode in aerated $3 \% \mathrm{NaCl}$ solution in the presence of $8.9 \mathrm{mmol} \mathrm{L}{ }^{-1}$ BAMTB with the immersion time as a parameter. $\Omega=1000 \mathrm{rpm}$.

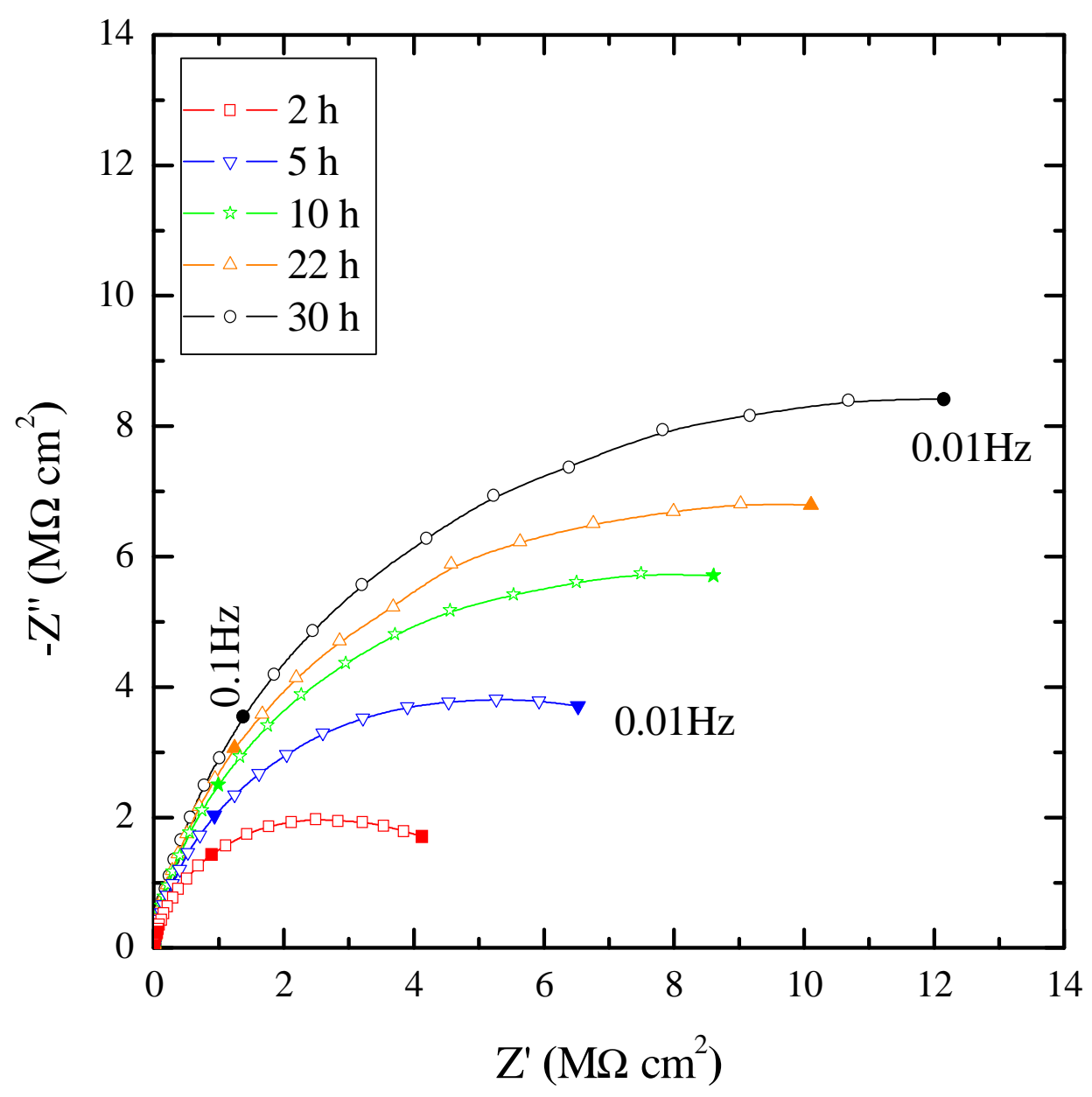


Figure 6: Variation of the film capacitance and the polarization resistance in a $3 \% \mathrm{NaCl}$ in presence of $8.9 \mathrm{mmol} \mathrm{L}^{-1}$ BAMTB with the immersion time as a parameter. $\Omega=1000 \mathrm{rpm}$.

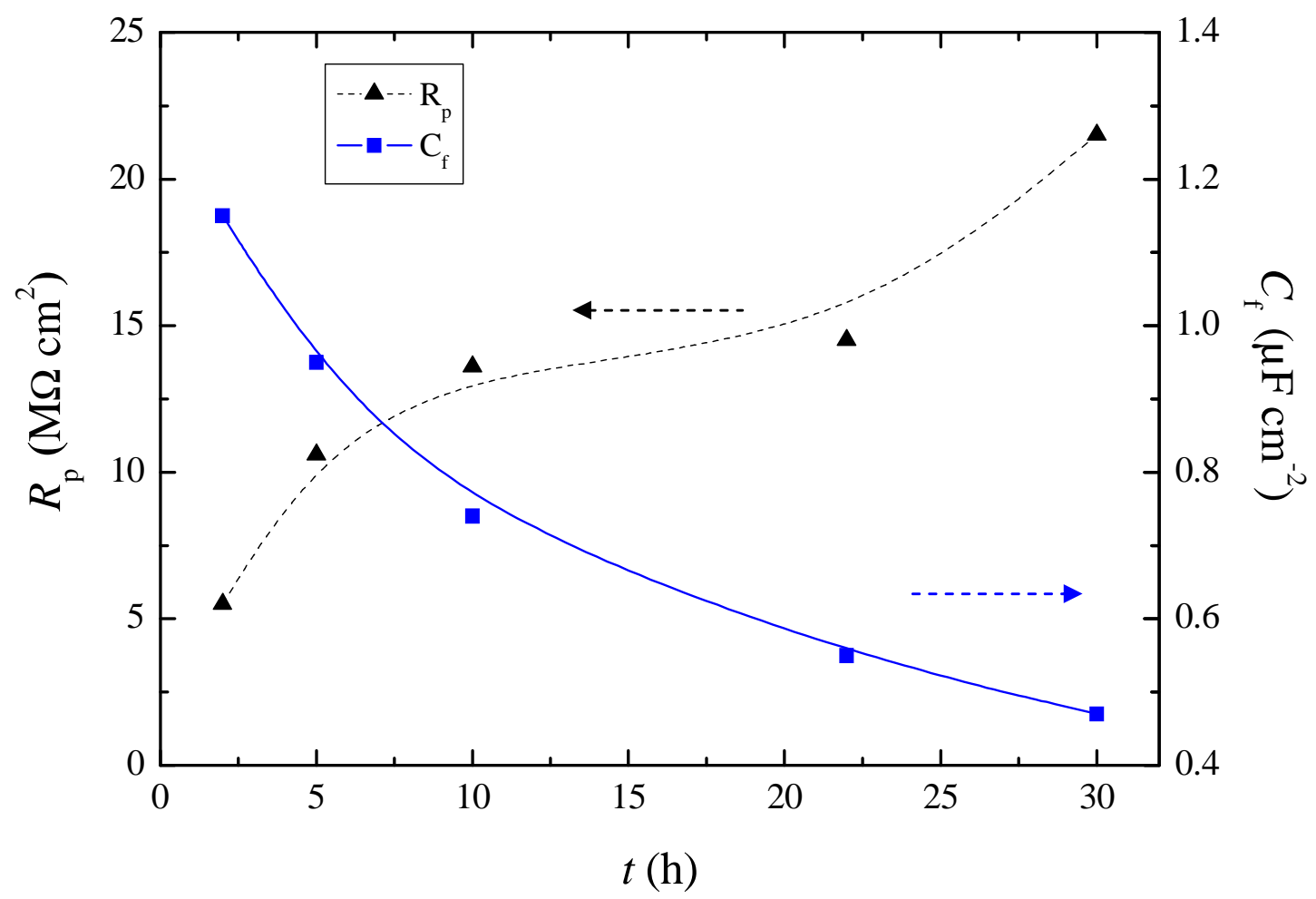


Figure 7: Variation of thickness as a function of the immersion time for copper electrode in a $3 \% \mathrm{NaCl}$ in presence of $8.9 \mathrm{mmol} \mathrm{L}{ }^{-1}$ of BAMTB. $\Omega=1000 \mathrm{rpm}$.

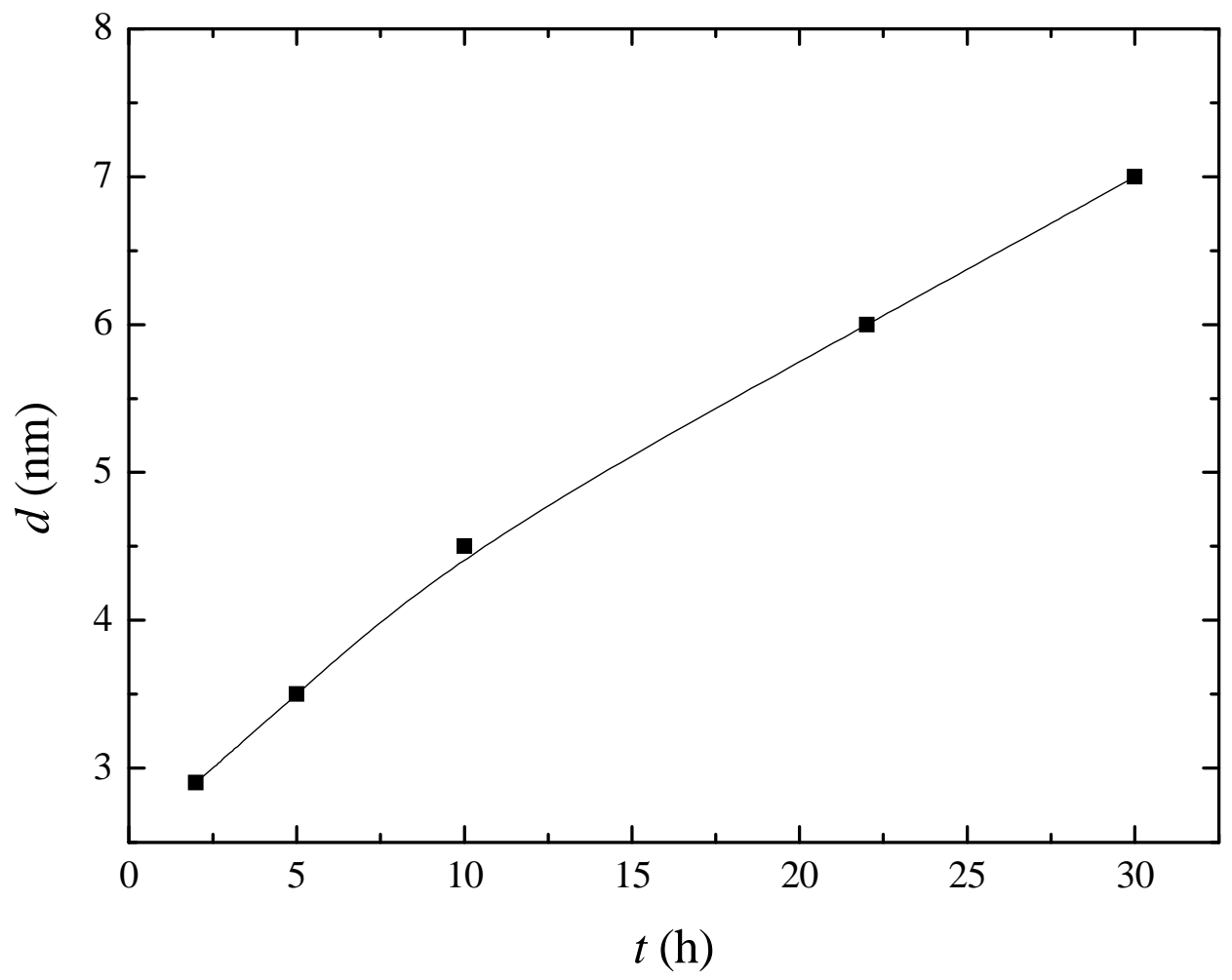


Figure 8: SEM images of the copper surface obtained (a) before and after 1 week immersion in a $3 \% \mathrm{NaCl}$ solution (b) without and (c) with $8.9 \mathrm{mmol} \mathrm{L}^{-1}$ BAMTB.

$$
\Omega=1000 \mathrm{rpm} \text {. }
$$
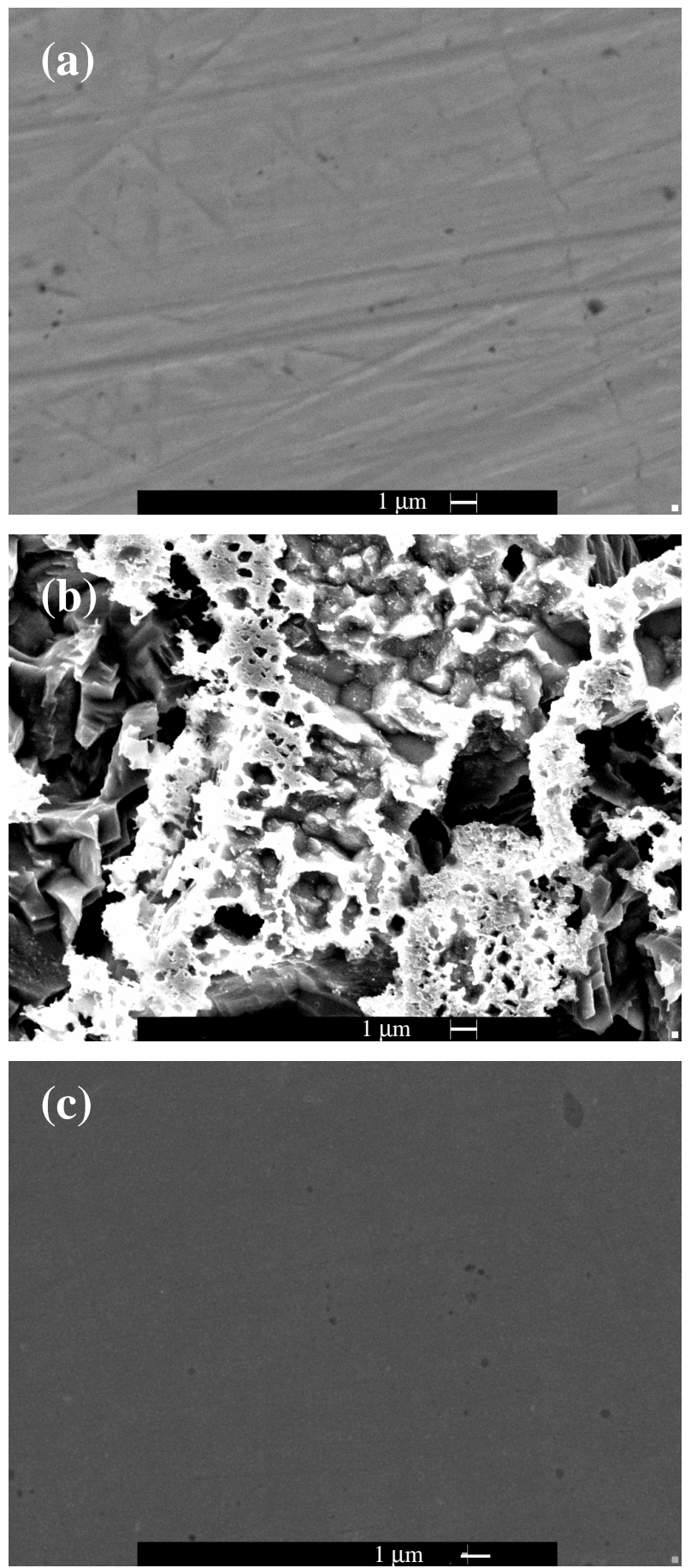
Figure 9: EDX analysis of copper obtained after 1 week of immersion in a $3 \% \mathrm{NaCl}$ (a) without BAMTB and (b) with $8.9 \mathrm{mmol} \mathrm{L}^{-1}$ BAMTB. $\Omega=1000 \mathrm{rpm}$.
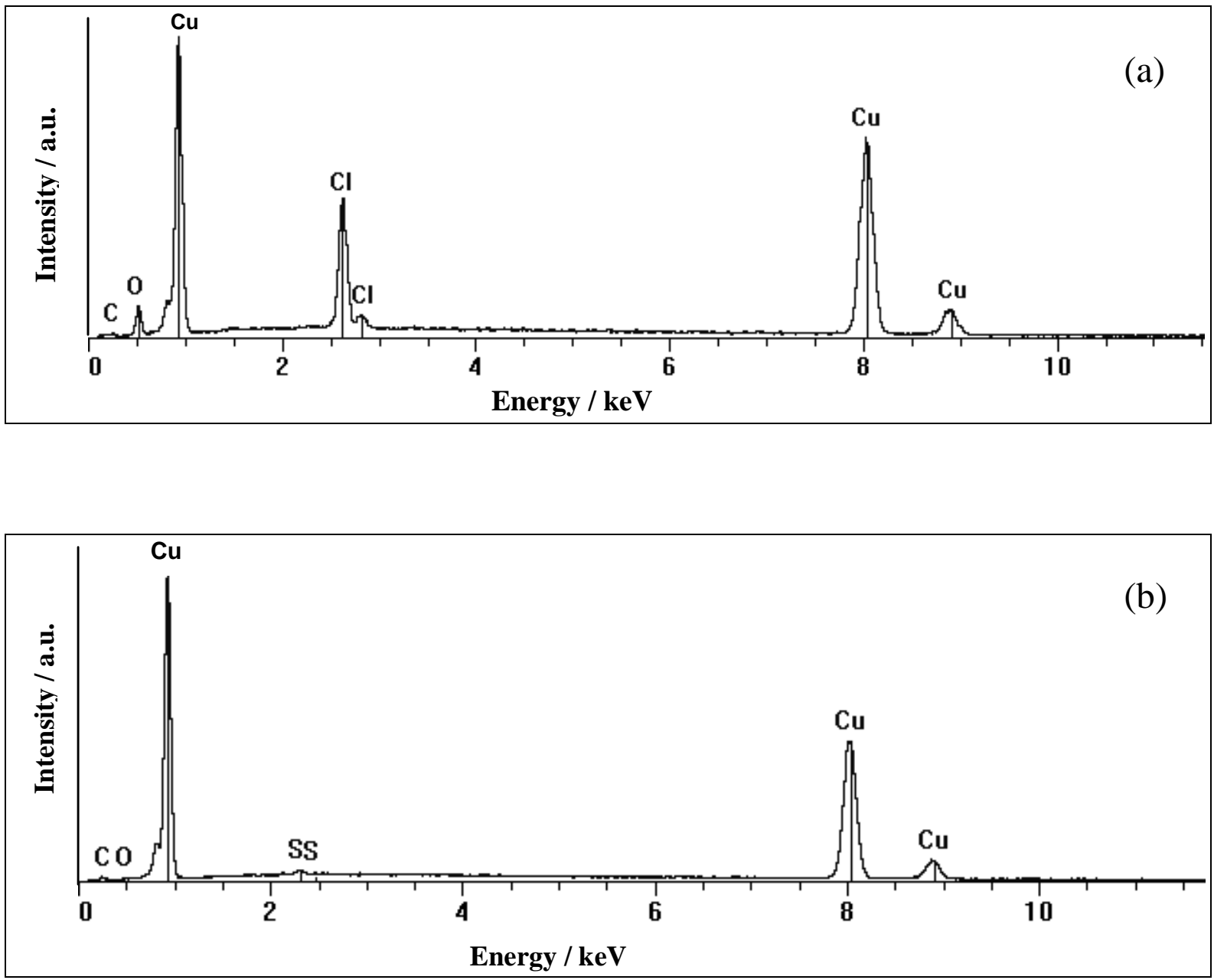
Figure 10. : Raman spectra of: (a) copper surface after 1 week of immersion in aerated $3 \%$ $\mathrm{NaCl}$; ( b) solid BAMTB; and (c) copper surface after 1 week of immersion in aerated $3 \%$ $\mathrm{NaCl}$ with $8.9 \mathrm{mmol} \mathrm{L}^{-1}$ BAMTB

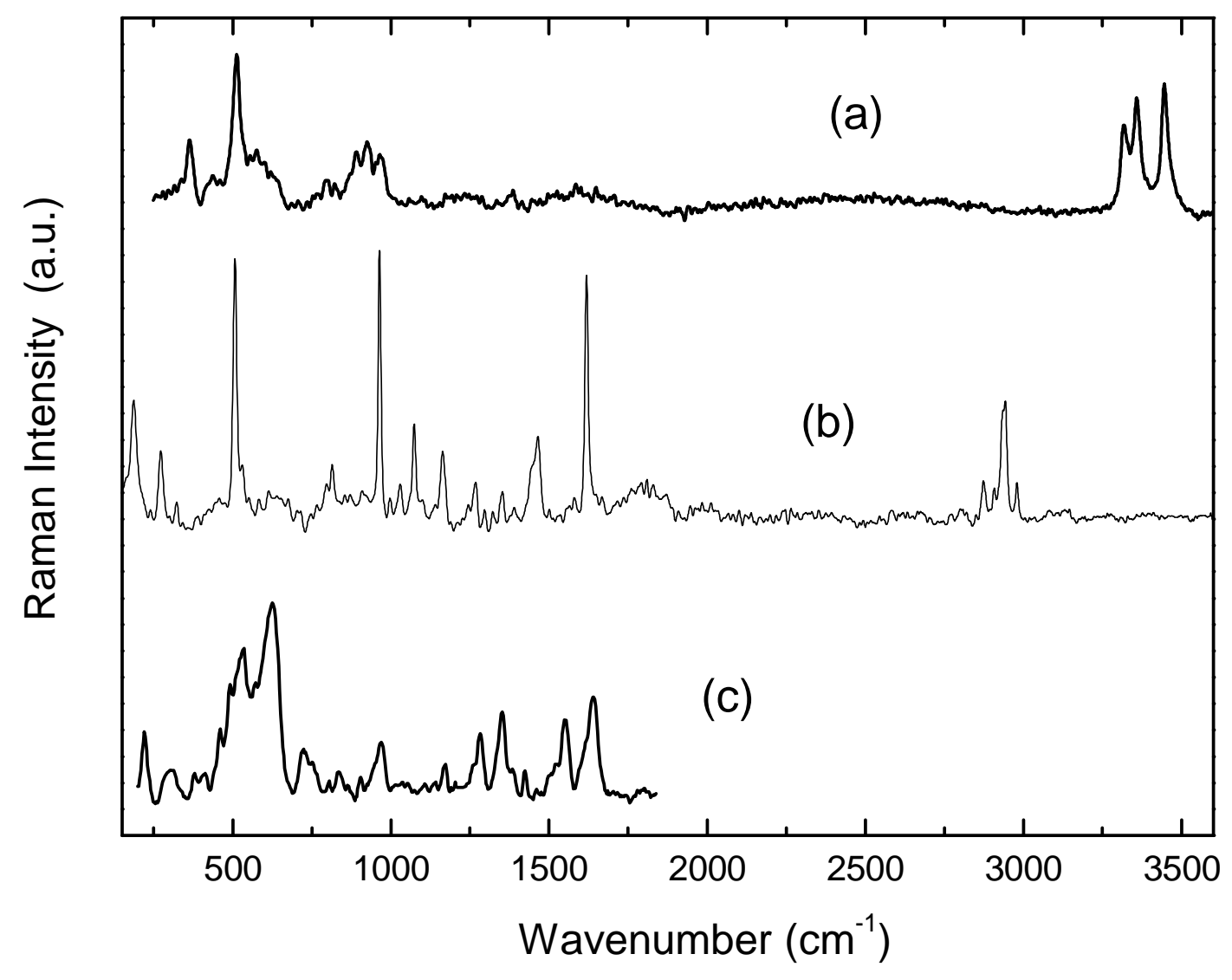


Figure 11: Chronoamperometric curves for a copper electrode biased at $150 \mathrm{mV} / \mathrm{SCE}$ in a $3 \%$ $\mathrm{NaCl}$ solution (a) in absence and (b) in presence of $8.9 \mathrm{mmol} \mathrm{L}^{-1}$ BAMTB. $\Omega=1000 \mathrm{rpm}$.
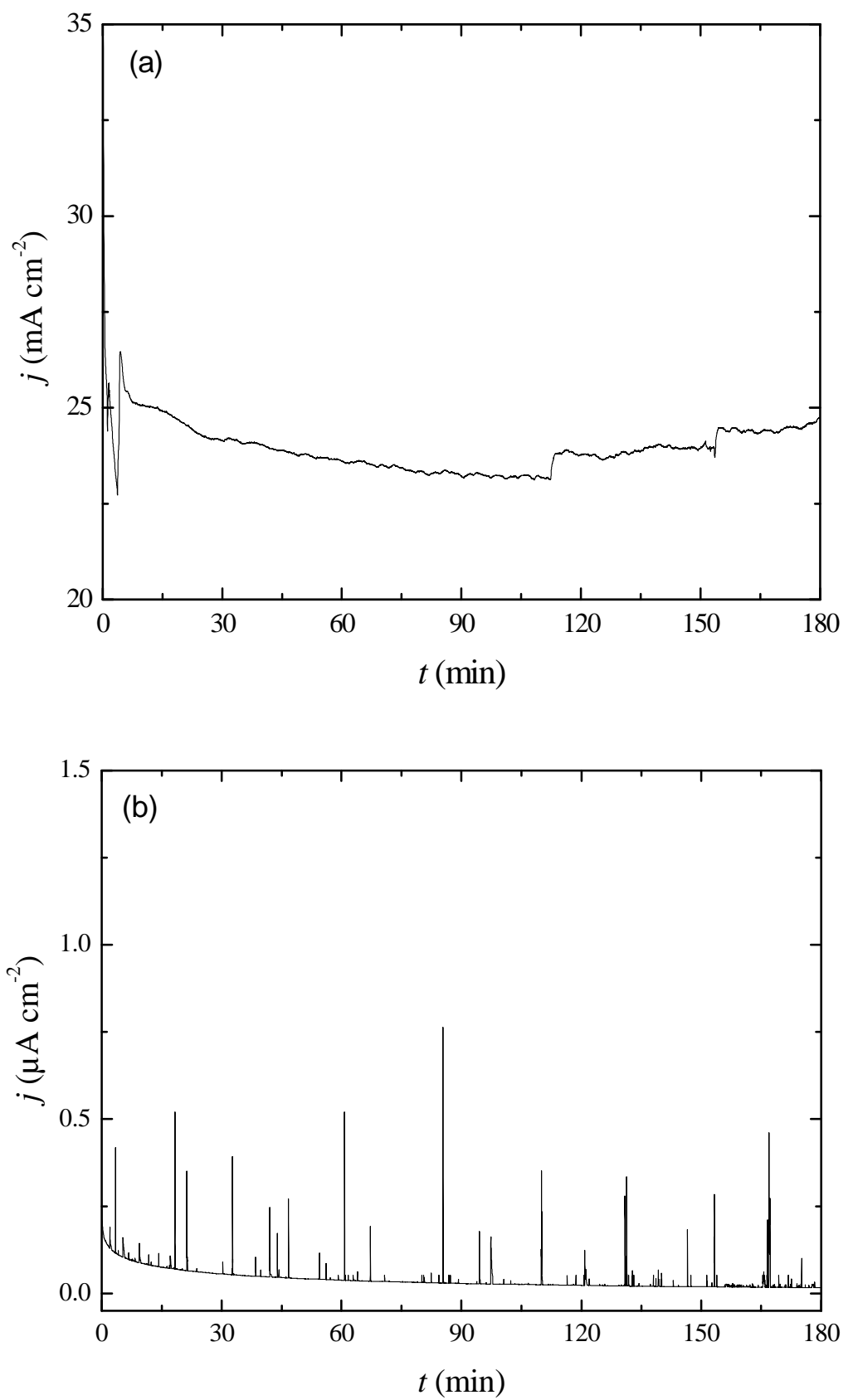
Figure 12: SEM images of the copper surface obtained after chronoamperometric experiments presented in Fig. 11. (a) without and (b) with $8.9 \mathrm{mmol} \mathrm{L}^{-1}$ BAMTB.
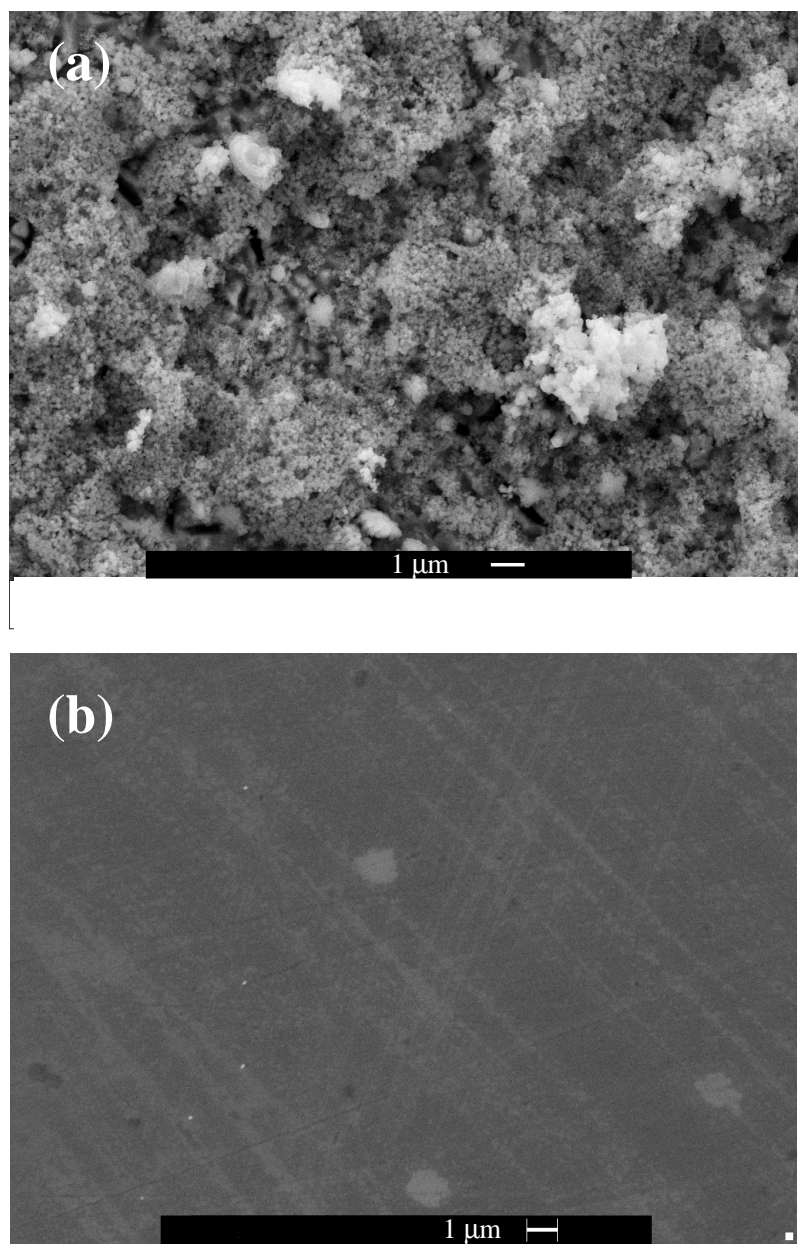